\title{
Adsorption of Hexavalent Chromium Ion from Aqueous Solution by Sodium Alginate and Carboxymethyl Cellulose Beads: Kinetics and Isotherm Studies
}

\author{
Ali J. Salim \\ Department of Chemistry, College of Science, Al-Mustansiriya University, Baghdad-Iraq. \\ E-mail: Alijs82@yahoo.com.
}

\begin{abstract}
The removal of hexavalent chromium from aqueous solutions using biopolymeric beads of crosslinked sodium alginate (SA) and carboxymethyl cellulose (SCMC) as the adsorbent is reported in this paper. The biopolymeric alginate and carboxymethyl cellulose beads were prepared and characterized by FTIR spectra. The studies of adsorption of $\mathrm{Cr}(\mathrm{VI})$ were conducted by varying various parameters: such as contact time, $\mathrm{pH}$, amount of adsorbent and concentration of adsorbate. A comparison of kinetic models applied to the adsorption of $\mathrm{Cr}(\mathrm{VI})$ ions on the adsorbents was evaluated for the pseudo-first-order, the pseudo second-order and intraparticle diffusion kinetic models respectively. Results show that the pseudo second-order kinetic model was found to correlate the experimental data well. The experimental equilibrium data were applied to Langmuir and Freundlich isotherm models and their equilibrium parameters were estimated.
\end{abstract}

Keywords: adsorption kinetic; carboxymethyl cellulose; sodium alginate.

\section{Introduction}

The heavy metal pollution is of great concern among the kinds of environmental pollution because of their high toxicity and other adverse effects on human health [1]. Heavy metals like chromium, copper, lead, zinc, mercury, cadmium etc. are present in waste water from several industries such as metal cleaning and plating baths, refineries, paper and pulp, tanning, dyes and pigments, wood preserving, glass, ceramic paints, catalysis chemical manufacturing etc. in which chromium (VI) is present from 5 to $220 \mathrm{mg} / \mathrm{dm}^{3}$ which leave into environment [2-3].

Chromium can be released to the environment through a large number of industrial operation. Including metal finishing industry, iron and steel industries and inorganic chemicals production. There are various methods to remove $\mathrm{Cr}(\mathrm{VI})$ including chemical precipitation, membrane process, ion exchange, liquid extraction and electro dialysis [4]. But most of these methods have many disadvantages including incomplete metal removal, use of expensive equipment, and higher energy consumption adsorption remain the most economical of toxic metal ions from waste water [5].

The biosorption is the passive, nonmetabolic process of binding various chemicals on biomass, including physicochemical interactions, adsorption and ionexchange. In the case of biosorption, ionexchange is the most important mechanism that is realized by interaction between metal ions and active groups present in biopolymers. Thus by immobilization of biomass in a polymeric matrix that yields beads or granules with optimum size, mechanical strength, rigidity and porosity characteristics, the efficient removal of metal ions can be carried out. [6] The research for high biomass sorption is expected to improve the potential for the introduction of new materials, which are likely to be competitive and cost efficient for the sorption of metals. One of the most widely studied naturally occurring biopolymers are polysaccharide based biosorbents such as alginate and carboxymethyl cellulose (CMC) which have binding sites for divalent cations due to the presence of various functional groups within them. [7].

Sodium carboxymethyl cellulose (SCMC) is an important biopolymer due to its high degree of solubility in water, biocompatible, nontoxic and low cost [8]. SCMC has been widely used as thickening agent and stabilizing agent in industrial field [9]. Alginates have been used extensively in the food, cosmetics, pharmaceutical and biomedical industries for their gel forming properties in the presence of 
multivalent cations [10]. Alginates can make a gel in the presence of divalent and trivalent cations including $\mathrm{Ca}^{2+}$ and $\mathrm{Al}^{3+}$. It has been shown that the exchange of the sodium ions from the guluronic acids with divalent ions, and the stacking of these guluronic groups, form a so-called egg-box structure [11].

The aim of this work was to study the adsorption of chromium (VI) from aqueous solution using sodium alginate and sodium carboxymethyl cellulose beads was investigated in this study the effect of factors such as contact time, initial concentration, $\mathrm{pH}$, and adsorbent dose were investigated. langmiur and freundlich isotherms were evaluated and kinetics studied.

\section{Experimental}

\section{1- Material}

Sodium carboxymethyl cellulose and sodium alginate were purchased from sigma Aldrich and used as received, while alumium chloride and potassium dichromate of analar grade from $(\mathrm{BDH})$.

\section{2- Instrumentation}

Water bath shaker type lab companion BS11, digital scale KERN-ABBS, UV-Visible spectrometer, CARY 100 con. pH meter type trans BP 300, shimadzu 8400 FTIR were employed in this work.

\section{3- Preparation of biopolymeric beads}

The polymer beads adsorbente were prepared by ionic gelation method by using alumium chloride as cross-linking agent, prepared in two steps: in the first step. Aknown solution of a mixture of carboxymethyl cellulose (2g.) and sodium alginate (2g.) in $100 \mathrm{ml}$. distilled water was added in to a $100 \mathrm{ml}$. solution of $6 \% \mathrm{w} / \mathrm{v}$ of gelling agents solution with the help of asyring with constant stirring. The beads were removed after the gelation period of $30 \mathrm{~min}$. using Millipore stainless steel sieve (pore size: $0.25 \mathrm{~mm}$ ) and washed with distilled water repeatedly to make it free from un-reacted ions. These biopolymeric beads were stored at room temperature and the swollen beads were used for the adsorption of $\mathrm{Cr}(\mathrm{VI})$.

\section{4- Adsorption experiments}

Astock solution of potassium dichromate of $1000 \mathrm{mg} / \mathrm{L}$ was prepared. from these stock solution dilute concentrations of $\mathrm{Cr}(\mathrm{VI})$ was prepared by dilution of specified volume of stock solution $50 \mathrm{ml}$ of certain concentrations of $\mathrm{Cr}(\mathrm{VI})$ was stirred with certain amount of biopolymeric beads in water bath shaker for definite time interval. At the end of each adsorption experiment the solution was made alkaline at $\mathrm{PH}=12$ and the residual $\mathrm{Cr}(\mathrm{VI})$ was determined using UV-Visible spectrophotometer [12]. For calibrating the UV-Visible spectrophotometer standard sample of dichromate was prepared and corresponding adsorption for each concentration was measured at $\chi \max 372 \mathrm{~nm}$. The removal percentage $\mathrm{R} \%$ of $\mathrm{Cr}(\mathrm{VI})$ was calculated using the following equation.

$\mathrm{R} \%=\frac{\left(\mathrm{C}_{\mathrm{i}}-\mathrm{C}_{\mathrm{e}}\right)}{\mathrm{C}_{\mathrm{i}}} \times 100$

Were, $C_{i}$ and $C_{e}$ are the initial and final concentration $(\mathrm{mg} / \mathrm{L})$ of $\mathrm{Cr}(\mathrm{VI})$.

\section{Adsorption and Kinetics Studies}

Effects of some selected reaction parameters on the rates of adsorption of $\mathrm{Cr}(\mathrm{VI})$ using the sodium alginate (SA) and sodium carboxymethyl cellulose (SCMC). The parameters considered include agitation time, adsorbent dosage, $\mathrm{pH}$ and initial concentration. To study the effect of agitation time on metal adsorption by SA, SCMC different contact durations $(5,10,20,30,40,50$ and $60 \mathrm{~min})$ was tested. After each agitated time, the content of the bottle was filtered and the equilibrium concentration of each of the metals in the filtrate was determined.

The effect of adsorbent dosage, that is, the amount of SA, SCMC on the adsorption of metals was studied by adding $50 \mathrm{~mL}$ of the $\mathrm{Cr}(\mathrm{VI})$ to various amounts of the adsorbent $\left(\begin{array}{lll}0.05 & -0.5 \mathrm{~g}\end{array}\right)$ in different plastic bottles covered and agitated by mechanical shaker.

The equilibrium time and the $\mathrm{pH}$ were kept constant during this test. To determine the effect of $\mathrm{pH}$ on the adsorption of $\mathrm{Cr}(\mathrm{VI})$, the $\mathrm{pH}$ of the wastewater was adjusted and maintained to the required value $(1.0,2.0,3.0$, 4.0, 5.0 and 6.0) with $0.1 \mathrm{M} \mathrm{HCl}$ and $0.1 \mathrm{M}$ $\mathrm{NaOH}$ solution and mixed with the optimum 
weight of the adsorbent and agitated at a preset equilibrium time. The adsorption capacity $\left(\mathrm{q}_{\mathrm{e}}\right)$ was determined using the mass balance expression (Equation 2)[13].

$$
\mathrm{q}_{\mathrm{e}}=\frac{\left(\mathrm{C}_{\mathrm{i}}-\mathrm{C}_{\mathrm{e}}\right) \times \mathrm{V}}{\mathrm{M}}
$$

Also, the adsorption capacity $\left(\mathrm{q}_{\mathrm{t}}\right)$ at time $t$ was determined using the Equation (3)[14].

$$
\mathrm{q}_{\mathrm{t}}=\frac{\left(\mathrm{Co}-\mathrm{C}_{\mathrm{t}}\right) \times \mathrm{V}}{\mathrm{M}}
$$

Where $\mathrm{C}_{\mathrm{o}}$ is the initial metal ions concentration, $\mathrm{C}_{\mathrm{e}}$ is the concentration of metal ions in solution $(\mathrm{mg} / \mathrm{L})$ at equilibrium, $C_{t}$ is the concentration of metal ions in solution $(\mathrm{mg} / \mathrm{L})$ at time $\mathrm{t}$ in solution, $\mathrm{V}$ is volume of initial metal ions solution used $(\mathrm{L})$ and $\mathrm{M}$ is mass of adsorbent used ( $\mathrm{g}$ ).

Furthermore, kinetics of adsorption was studied by analyzing the adsorptive uptake of $\mathrm{Cr}(\mathrm{VI})$ at different time intervals. The pseudo - first - order, pseudo - second - order and Intrapartical Diffusion model equations were fitted to the kinetics of adsorption $\mathrm{Cr}$ (VI) onto SA,SCMC. The linearity of each model, when plotted, was used to find out how suitable each model illustrate the adsorption.

\section{Adsorption Isotherm}

Adsorption isotherm experiments were carried out at different temperatures $(25,35,45)^{\circ} \mathrm{C}$ by shaking the biopolymer beads $(0.2 \mathrm{~g})$ with $50 \mathrm{ml}$ of $\mathrm{Cr}(\mathrm{VI}) 10,20,30,40,50$ and $60 \mathrm{mg} / \mathrm{L}$ solution for 60 minutes at $\mathrm{pH} 2$. The amount of $\mathrm{Cr}(\mathrm{VI})$ adsorbed onto the biopolymer beads.

\section{Result and Discussion}

\subsection{FTIR spectra}

Fig. (1), shows the FT-IR spectrum of the SCMC. The absorption peaks at 3313 and $3184 \mathrm{~cm}^{-1}$ were assigned to the stretching vibration of $2^{0}$ and $1^{0} \mathrm{O}-\mathrm{H}$ group respectively. The peak at $2916 \mathrm{~cm}^{-1}$ was due to the stretching vibration of aliphatic $\mathrm{C}-\mathrm{H}$. The peak at $1602 \mathrm{~cm}^{-1}$ is due to asymmetrical stretching vibration of $\mathrm{COO}^{-}$groups. Similar peak at 1442 and $1317 \mathrm{~cm}^{-1}$ are assigned to symmetrical stretching vibration of $\mathrm{COO}^{-}$ groups. While the peak appear $1066 \mathrm{~cm}^{-1}$ is attributed to the $\mathrm{C}-\mathrm{O}-\mathrm{C}$ stretching vibration [15].

Fig.(2), shows the FT-IR of SA. The absorption peak at $3300 \mathrm{~cm}^{-1}$ represent the $\mathrm{O}-\mathrm{H}$ stretching vibration, the peak at $2926 \mathrm{~cm}^{-1}$ was due to the stretching vibration of aliphatic $\mathrm{C}-\mathrm{H}$. The absorption peaks at $1606 \mathrm{~cm}^{-1}$ and $1421 \mathrm{~cm}^{-1}$ was due to asymmetric and symmetric stretching vibration of $\mathrm{COO}^{-}$group [16], While the peak appear at $1022 \mathrm{~cm}^{-1}$ was due to the stretching vibration of $\mathrm{C}-\mathrm{O}-\mathrm{C}$ group.

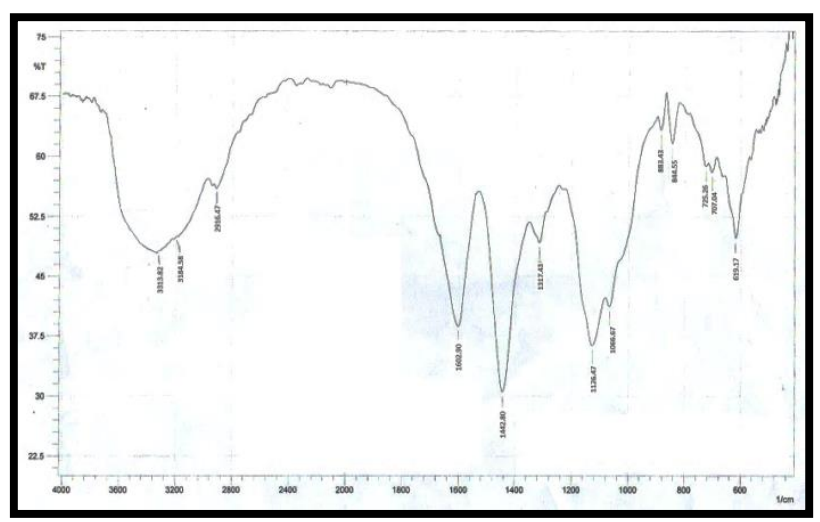

Fig.(1): FTIR Spectram of SCMC beads.

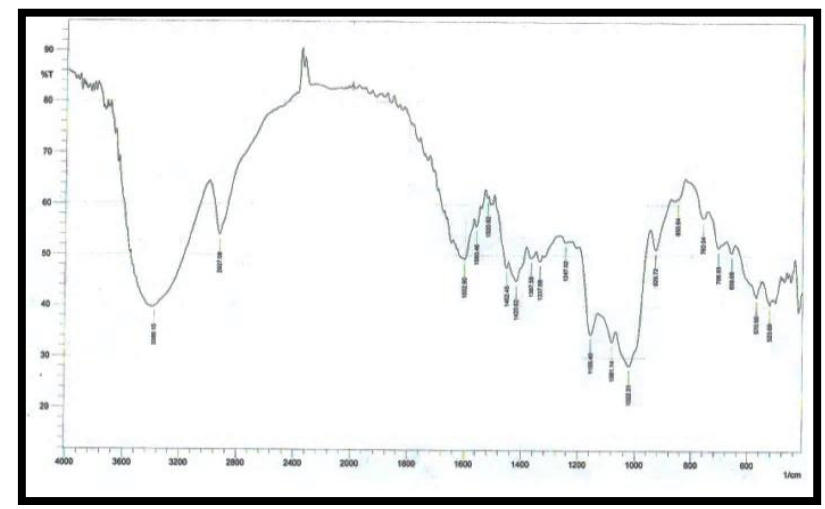

Fig.(2): FTIR Spectram of SA beads.

\subsection{Effect of contact time}

The amount of $\mathrm{Cr}(\mathrm{VI})$ adsorbed on SA and SCMC was studied as a function of shaking time. The results are given in Fig.(3). There was a rapid adsorption in the 40 minutes, then little change occurred with time. The percentage removal was $53.72 \%$ and $62.97 \%$ on to SA and SCMC respectively in the first 10 minutes. The percentage adsorption increased with increase the time and the percentage of removal $\mathrm{Cr}(\mathrm{VI})$ on $\mathrm{SA}$ and SCMC at 50 minutes reached $83.17 \%$ and $75.46 \%$ respectively. 


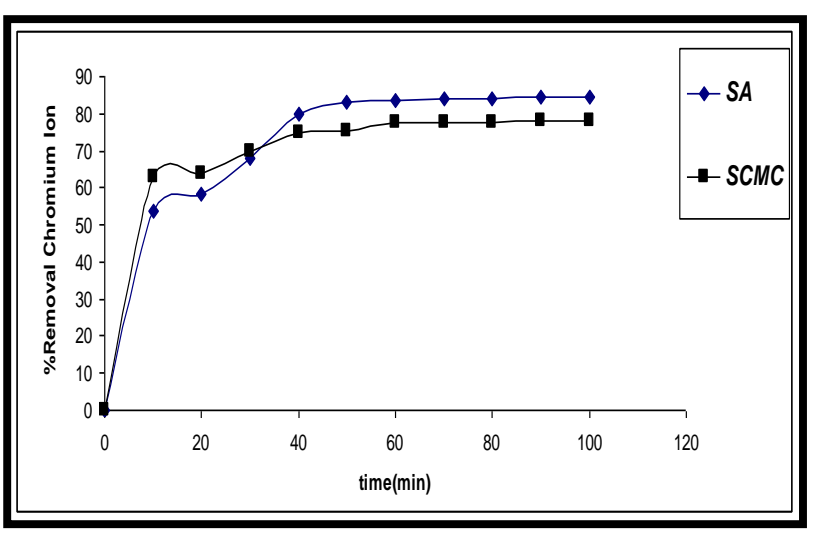

Fig.(3): Effect of contact time on the adsorption of $\mathrm{Cr}(\mathrm{VI})$ (initial concentration

$50 \mathrm{mg} / \mathrm{L}$, amount of adsorbent $=0.3 \mathrm{~g}$ $p H=2, T=30 C^{o}$, agitation speed $120 \mathrm{rpm}$.

\subsection{Effect of pH}

$\mathrm{pH}$ is an important parameter influencing heavy metal adsorption from aqueous solutions. Fig.(4) shows the percentage of $\mathrm{Cr}(\mathrm{VI})$ removal as a function of $\mathrm{pH}$. it is evident this figure that the percentage adsorption is higher at lower $\mathrm{pH}$. the maximum removal efficiency was $\% 79.25$ and $\% 72.47$ on SA and SCMC respectively. the best results were observed at $\mathrm{pH} 2$.

In view of an electrostatic interaction between the sorbent-sorbate systems, it was decided to maintain the $\mathrm{pH}$ at 3.0 in further experiments. It was also observed that at the end of the adsorption experiments, $\mathrm{pH}$ of the solution increased from 3.0 to 5.5. This might be attributed to the protonation of amine group, $\mathrm{HCrO}^{-}$reduction accompanied by $\mathrm{H}+$ consumption. and slow release of alkalinity from the prepared sorbent [17].

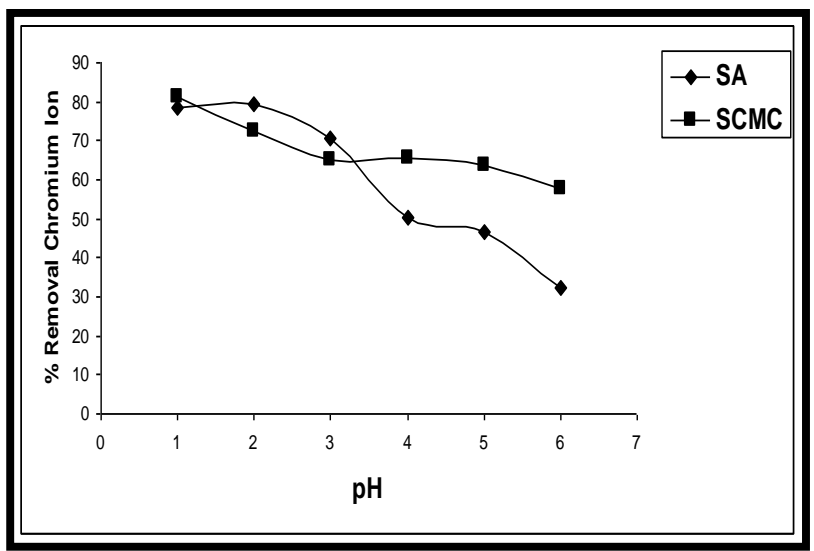

Fig.(4): Effect of pH on equilibirum concentration of $\mathrm{Cr}(\mathrm{VI})$ (initial concentration $=50 \mathrm{mg} / \mathrm{L}$, amount of adsorbent $=0.3 g, T=30 C^{o}$, agitation speed $120 \mathrm{rpm}$.

\subsection{Effect of adsorbent Dosage}

Various amounts of SA, SCMC (0.05 to 0.5) $\mathrm{g}$ were exposed for a $60 \mathrm{~min}$ to $50 \mathrm{ml}$ of $\mathrm{Cr}(\mathrm{VI})$ solution with the concentration of $50 \mathrm{mg} / \mathrm{L}$. Fig.(5) shows the removal efficiency of $\mathrm{Cr}(\mathrm{VI})$ against the amount of SA, SCMC used. The removal percentage increases by increasing of SA, SCMC amount. The percentage adsorption increased from $13.38 \%$ and $30 \%$ at lower adsorbent dose $(0.05 \mathrm{~g})$ to $75.52 \%$ and 84.54 at higher adsorbent dose $(0.5 \mathrm{~g}) \mathrm{SA}$ and SCMC respectively.

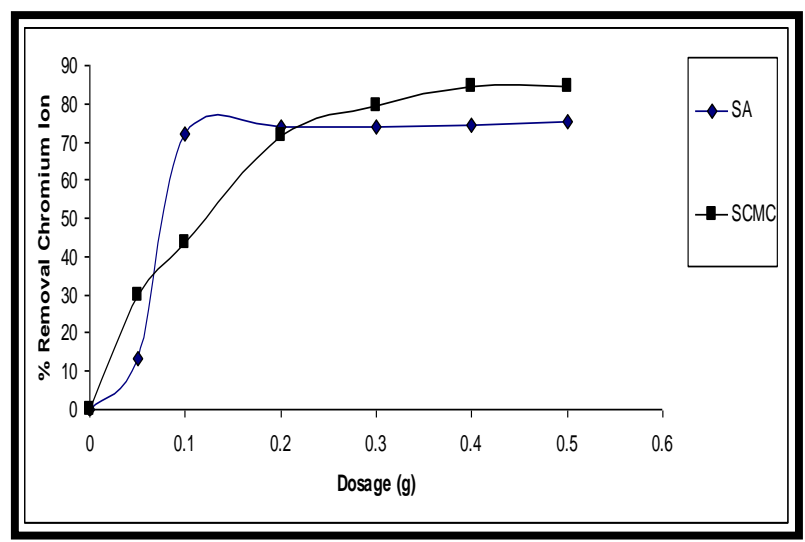

Fig.(5): Effect of Dosage on equilibirum concentration of $\mathrm{Cr}(\mathrm{VI})$ (initial concentration $=50 \mathrm{mg} / \mathrm{L}, \mathrm{pH}=2, \mathrm{~T}=30 \mathrm{C}^{\circ}$. agitation speed $120 \mathrm{rpm}$.

\subsection{Effect of initial concentration.}

The effect of adsorbate ion concentration was studies by taking 10,20,30,40,50 and $60 \mathrm{mg} / \mathrm{L}$ with an optimum $\mathrm{pH}$ value, Fig.(6). The adsorption capacity increased with an increase in the initial $\mathrm{Cr}(\mathrm{VI})$ concentration. This is because an opportunity existed for increased reaction between the adsorbent and the adsorbate [18].

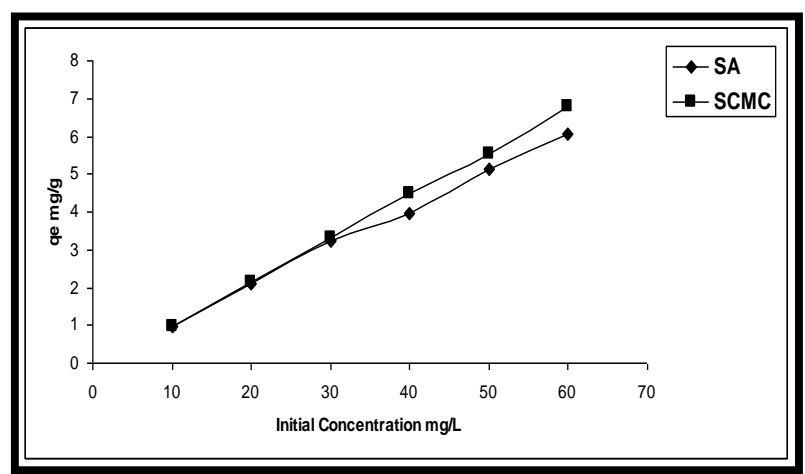

Fig.(6): Effect of Initial Concentration on equilibirum concentration of $\mathrm{Cr}(\mathrm{VI})$, amount of adsorbent $=0.3 \mathrm{~g}, \mathrm{pH}=2, \mathrm{~T}=30 \mathrm{C}^{\circ}$. agitation speed $120 \mathrm{rpm}$. 


\subsection{Adsorption kinetics modeling}

The adsorption kinetic models are important in the process of removal of toxic heavy metals from the aquatic environment. In this study of a batch reaction, different reversible models were tested.

\subsubsection{Pseudo-first order model}

The pseudo-first order model is one of the most widely used procedures for the adsorption of a solute from an aqueous solution [19]. The pseudo-first order equation can be expressed as follows:

$$
\log \left(\mathrm{q}_{\mathrm{e}}-\mathrm{q}_{\mathrm{t}}\right)=\log \mathrm{q}_{\mathrm{e}}-\frac{\mathrm{k}_{1}}{2.303} \mathrm{t}
$$

where $q t$ is the amount of metal ions adsorbed at time $t\left(\mathrm{mg} \mathrm{g}^{-1}\right)$, qe $\left(\mathrm{mg} \mathrm{g}^{-1}\right)$ is equilibrium solid phase concentration and $k 1$ is first order rate constant for adsorption $\left(\mathrm{min}^{-1}\right)$. The plot of $\log (q \mathrm{e}-q t) v s$. $t$ should result in a straight line. The rate constant can be calculated from the slope of the straight line (7).

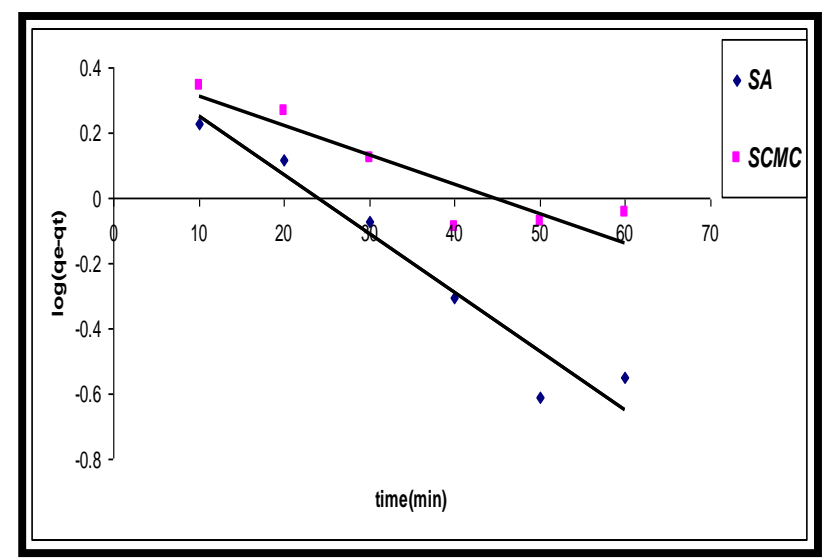

Fig.(7): First order plot of adsorption of $\mathrm{Cr}(\mathrm{VI})$ onto $\mathrm{SA}$ and $\mathrm{SCMC}$.

\subsubsection{Pseudo-second order model}

The pseudo-second order equation is based on the adsorption capacity of the solid phase. Contrary to other models, it predicts the behavior over the whole range of adsorption [20].Pseudo-second order model based on the equilibrium adsorption capacity may be expressed in the form:

$\left(\frac{t}{q_{t}}\right)=\frac{1}{k_{2} q_{e}^{2}}+\frac{1}{q_{e}}(t)$ where $k_{2}\left(\mathrm{~g} \mathrm{mg}^{-1} \mathrm{~min}^{-1}\right)$ is the rate constant of pseudo-second order adsorption. The plot of t/qt $v s$. $t$ should yield a straight line Fig.(8), which allows the computation of $k_{2}$.

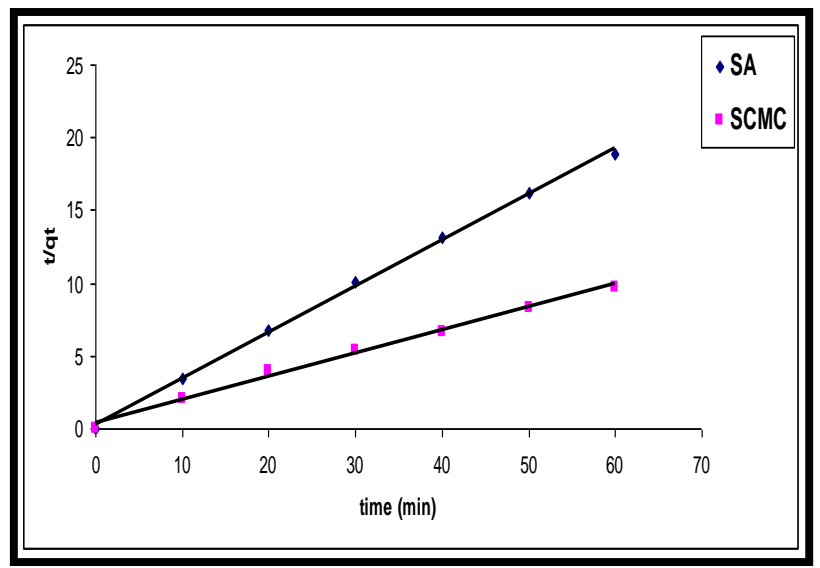

Fig.(8): Second-order plot of adsorption of $\mathrm{Cr}(\mathrm{VI})$ onto SA and SCMC.

\subsubsection{Intra-particle diffusion}

Intra-particle diffusion was explored using the intra-particle diffusion model given in Eq.(6).

$$
\mathrm{q}_{\mathrm{t}}=\mathrm{K}_{\text {dif }} \mathrm{t}^{1 / 2}
$$

where $k$ id is the intra-particle diffusion rate constant and the meanings of the other terms have already been defined. This model predicts that the plot of $q_{t} v s . t^{1 / 2}$ should be linear if intra-particle diffusion is involved in the sorption process Fig.(8). Intra-particle diffusion is the rate-controlling step if the line passes through the origin. [21]

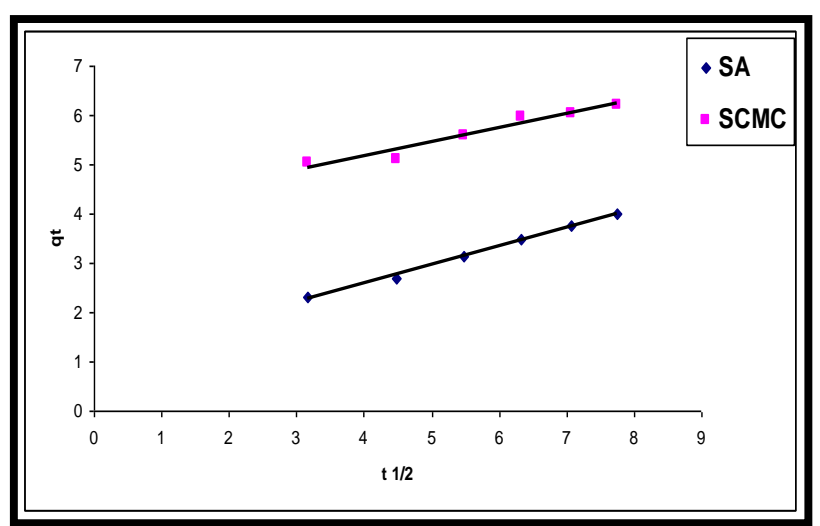

Fig.(9): Intrapartical Diffusion plot of adsorption of $\mathrm{Cr}(\mathrm{VI})$ onto SCMC and SA.

The application of the different kinetic models unveiled some interesting features regarding the mechanism and rate-controlling 
step of the overall sorption process. The kinetic parameters of $\mathrm{Cr}(\mathrm{VI})$ onto $\mathrm{SA}$ and SCMC under different conditions were calculated and are given in Table (1). To quantify the applicability of each model, the correlation coefficient, $R^{2}$, was calculated for these plots. The linearity of these plots indicates the applicability of the three models. However, the correlation coefficients, $R^{2}$, showed that the pseudo-second-order model, fits better the experimental data $\left(R^{2} \geq 0.9983\right)$ than the pseudo-first-order and the intraparticle diffusion kinetic models Table (1) and Fig. $(8,9)$.
While the linear curve of the second-order kinetic model were obtained when $\mathrm{t} / \mathrm{q}_{\mathrm{t}}$ was plotted against time, for the adsorption of $\mathrm{Cr}(\mathrm{VI})$ onto SA and SCMC in Fig.(8). The results reveal that the second-order kinetic model well represents the experimental data for the adsorption of $\mathrm{Cr}(\mathrm{VI})$ onto $\mathrm{SA}$ and SCMC, this conclusion came from the good correlation coefficient obtained from secondorder plot as well as the good match between the values of $\mathrm{qe}_{\mathrm{e}}(\mathrm{cal})$ and $\mathrm{q}_{\mathrm{e}}(\mathrm{exp})$ [22]. Table(1).

Table (1)

Kinetic parameters for the adsorption of Cr (VI) onto SA and SCMC.

\begin{tabular}{|c|c|c|}
\hline Adsorbent & $\overline{\mathrm{SA}}$ & SCMC \\
\hline \multicolumn{3}{|c|}{ Pseudo-first-order model } \\
\hline $\begin{array}{l}\mathrm{k}_{1} / 10^{-2} \min ^{-1} \\
\mathrm{R}^{2} \\
\text { qe (experimental), } \mathrm{mg} \mathrm{g}^{-1} \\
\text { qe (kinetic plot), } \mathrm{mg} \mathrm{g}^{-1}\end{array}$ & $\begin{array}{l}0.051 \\
0.872 \\
3.185 \\
2.578 \\
\end{array}$ & $\begin{array}{l}0.026 \\
0.987 \\
6.191 \\
1.968 \\
\end{array}$ \\
\hline \multicolumn{3}{|c|}{ Pseudo-second-order model } \\
\hline $\begin{array}{l}\mathrm{k}_{2} / 10^{-4} \mathrm{~g} \mathrm{mg}-1 \mathrm{~min}^{-1} \\
\mathrm{R}^{2} \\
\text { qe (experimental), } \mathrm{mg} \mathrm{g}^{-1} \\
\text { qe (kinetic plot), } \mathrm{mg} \mathrm{g}^{-1}\end{array}$ & $\begin{array}{l}0.261 \\
0.994 \\
3.185 \\
3.162 \\
\end{array}$ & $\begin{array}{c}0.06 \\
0.998 \\
6.191 \\
6.297 \\
\end{array}$ \\
\hline \multicolumn{3}{|c|}{ Intra-particle diffusion model } \\
\hline $\begin{array}{l}\mathrm{k}_{\text {dif }} / \mathrm{mg} \mathrm{g}-1 \mathrm{~min}^{-1 / 2} \\
\mathrm{R}^{2}\end{array}$ & $\begin{array}{l}0.2817 \\
0.9439 \\
\end{array}$ & $\begin{array}{c}0.379 \\
0.9962 \\
\end{array}$ \\
\hline
\end{tabular}

\section{Adsorption Isotherms}

Adsorpion isotherm are essential for the description of how metal ion concentration will interact with the adsorbent surface and are useful to optimize the adsorbent for the removal of $\mathrm{Cr}(\mathrm{VI})$ ions. The equilibrium adsorption isotherms are one of the most important data to understand the mechanism of the sorption. Several isotherm equations are available and two important isotherm are selected in this study, which are namely the Langmuir and Freundlich isotherms.

\section{Langmuir isotherm}

Assumes monolayer adsorption onto a surface containing a finite number of adsorption sites of uniform strategies of adsorption with no transmigration of adsorbate in the plane of surface. The linear form of Langmuir isotherm equation is given as

$\frac{1}{q_{e}}=\left(\frac{1}{K_{L} Q_{m}}\right) \frac{1}{C_{e}}+\frac{1}{Q_{m}}$

where $\mathrm{Ce}$ is the equilibrium concentration of the adsorbate $(\mathrm{mg} / \mathrm{L})$, qe is the amount of adsorbate adsorbed per unit mass of adsorbent $(\mathrm{mg} / \mathrm{g}), \mathrm{Q}_{\mathrm{m}}$ and $\mathrm{K}_{\mathrm{L}}$ are Langmuir constants related to adsorption capacity and rate of adsorption [23] The Langmuir plots for the $\mathrm{Cr}(\mathrm{VI})$ adsorption by SA and SCMC is given in Fig.(10) from values of $\mathrm{R}^{2}$ the langmiur isotherm is not applicable. 


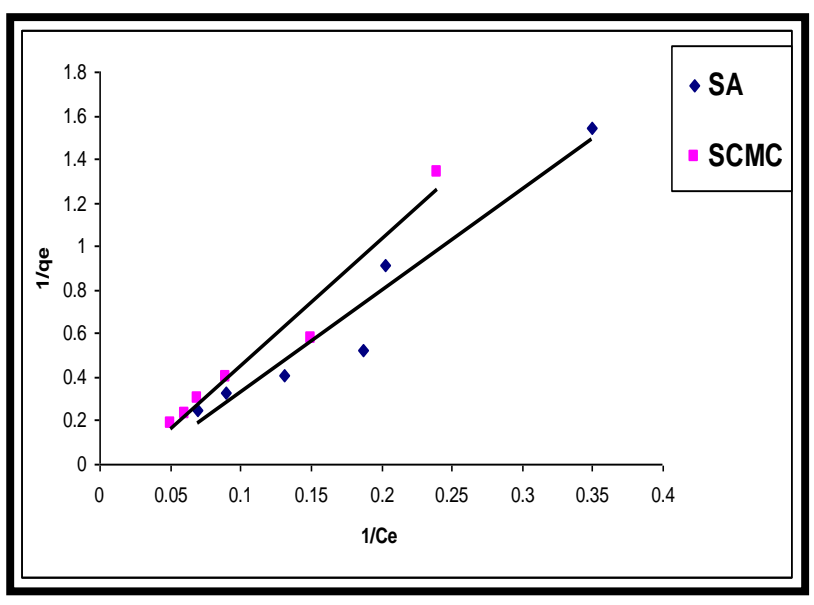

Fig.(10): Langmuir adsorption isotherm for adsorption of $\mathrm{Cr}(\mathrm{VI})$ at $\mathrm{pH} 2$, (initial concentration $50 \mathrm{mg} / \mathrm{L}$, amount of adsorbent $=0.3 \mathrm{~g}, \mathrm{~T}=30 \mathrm{C}^{\circ}$, agitation speed $120 \mathrm{rpm}$.

\section{Freundlich isotherm}

The linear form of freundlich isotherm (24) is represented by the equation

$\log \mathrm{Q}_{\mathrm{e}}=\log \mathrm{K}_{\mathrm{f}}+\frac{1}{\mathrm{n}} \log \mathrm{C}_{\mathrm{e}}$

where $\mathrm{Ce}$ is the equilibrium concentration of the adsorbate $(\mathrm{mg} / \mathrm{L})$ and qe is the amount of adsorbate adsorbed per unit mass of adsorbent $(\mathrm{mg} / \mathrm{g})$. Kf and $\mathrm{n}$ are Freundlich constants representing the adsorption capacity and intensity of adsorption respectively. The values of $\mathrm{Kf}$ and $1 / \mathrm{n}$ were obtained from the slope and intercept of the plot of log qe verses $\log \mathrm{Ce}$. The slope of $1 / \mathrm{n}$ ranging between 0 and 1 is a measure of adsorption intensity or surface heterogeneity, becoming more heterogeneous as its value gets closer to zero [24]. Freundlich constants $\mathrm{Kf}$ and $\mathrm{n}$ are listed in Table (2). The Freundlich plots for the $\mathrm{Cr}(\mathrm{VI})$ adsorption by SA and SCMC is given in Fig.(11) from values of $\mathrm{R}^{2}$ the freundlich isotherm is not applicable.

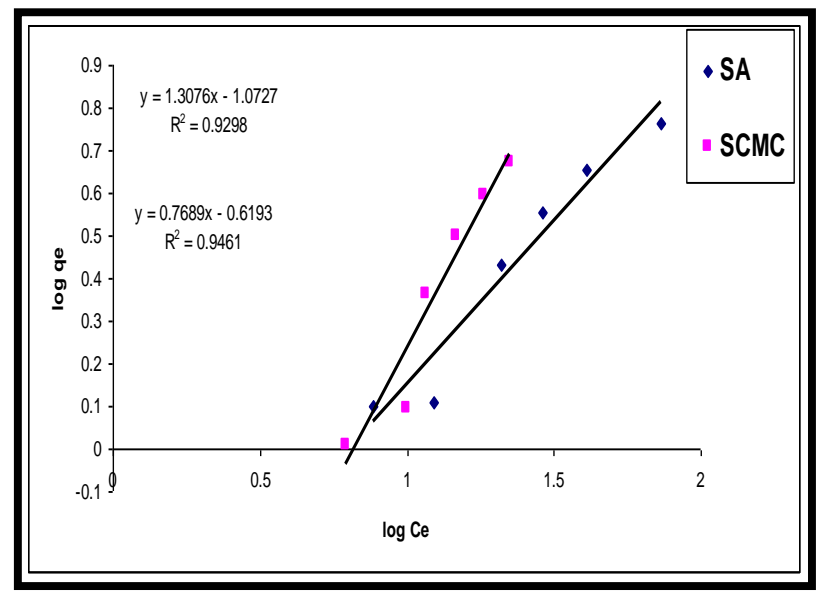

Fig.(11): Freundlich adsorption isotherm for adsorption of $\mathrm{Cr}(\mathrm{VI})$ at $\mathrm{pH} 2$, (initial concentration $50 \mathrm{mg} / \mathrm{L}$, amount of adsorbent $=0.3 \mathrm{~g}, \mathrm{~T}=30 \mathrm{C}^{\circ}$, agitation speed $120 \mathrm{rpm}$.

Table (2)

Values of the Langmuir and Freundlich constants for the adsorption of Cr (VI) onto $S A$ and $S C M C$.

\begin{tabular}{|ccccccc|}
\hline \multicolumn{2}{|c}{ Absorbent } & \multicolumn{2}{c}{ langmiur } & & \multicolumn{3}{c|}{ freundich } \\
\hline \hline $\mathrm{Qm} \mathrm{mg} / \mathrm{g}^{-1}$ & $\mathrm{k}_{\mathrm{L}} \mathrm{Lmg}^{-1}$ & $\mathrm{R}^{2}$ & $\mathrm{~K}_{\mathrm{f}}$ & $\mathrm{g}^{-1} \mathrm{~L}^{\mathrm{n}} \mathrm{mg}^{1-\mathrm{n}}$ & $\mathrm{n}$ & $\mathrm{R}^{2}$ \\
\hline \hline $\mathrm{SCMC}$ & 7.56 & 0.02 & 0.9642 & 4.161 & 1.3 & 0.9461 \\
$\mathrm{SA}$ & 6.87 & 0.031 & 0.9438 & 4.820 & 0.76 & 0.9298 \\
\hline
\end{tabular}

\section{Conclusion}

Biopolymeric beads of crosslinked carboxymethyl cellulose and sodium alginate proved to be an effective adsorbent for removal of $\mathrm{Cr}(\mathrm{VI})$ from aqueous solutions. The adsorption of $\mathrm{Cr}(\mathrm{VI})$ ion dependent on initial concentration of the metal ion, adsorbent dose, $\mathrm{pH}$ and contact time. The optimal condition for adsorption of $\mathrm{Cr}(\mathrm{VI})$ using SA and SCMC was $\mathrm{pH} 2$, contact time $40 \mathrm{~min}$ and initial concentration $50 \mathrm{mg} / \mathrm{L}$. The kinetics and isotherm studies indicated that the pseudo-first-order, pseudo-second-order,
Intrapartical Diffusion, Langmuir and Freundlich model well described the adsorption equilibrium of $\mathrm{Cr}(\mathrm{VI})$ ion onto SA and SCMC adsorption followed pseudosecond-order and Intrapartical Diffusion kinetics.

\section{Acknowledgment}

We are grateful to the ministry of higher education and scientific research for financial support of this work. 


\section{References}

[1] Gao H., Liu Y., Zeng G., Xu L and Xia W, "Characterization of $\mathrm{Cr}(\mathrm{VI})$ removal from aqueous solution by surpius agricural waste-Rice straw". J Hazard. Mater., 150(2),446-452, 2007.

[2] Saravanan A, Brindha V, Manimekalai R, Krishnan S , "An evaluation of chromium and zinc biosorption by a sea weed (Sargassum sp.) under optimized conditions", J. Sci. Technol.(2) 53-56, 2009.

[3] Ghosh P K, "Hexavalent chromium [Cr(VI)] removal by acid modifiedwaste activated carbons", J. Hazard. Mater. 171(1-3), 116-122, 2009.

[4] Lokendra T and Mukesh P, "Adsorption of heavy metal $(\mathrm{Cu} 2+, \mathrm{Ni} 2+$ and $\mathrm{Zn} 2+)$ from synthetic waste water by tea waste adsorbent" Int J of Chem and Phy Sc, 2(6), 6-19, 2013.

[5] Li Q, Zhai J, Zhang, W Wang, M Zhou, J, "Kinetic studies of adsorption of pb(II), $\mathrm{Cr}$ (III) and $\mathrm{Cu}$ (II) from aqueous solution by sawdust and modified peanut husk", J.hazard. Mater, 144(1), 163-167, 2007.

[6] Tsezos M, "Engineering Aspects of Metal Binding by Biomass"; Mc Grow Hill: New York, 325, 1990.

[7] Jang L. K, Geesey, G. G; Lopez, S. L "Water Resour", 24, 889, 1990.

[8] Tonnesen H H, Karlsen J, "Alginate in drug delivery systems". Drug Dev. Ind pharm 28, 621-630, 2002.

[9] Hoeffer A C, "Sodium Carboxymethyl Cellulose: Chemistry, Functionality, and Applications.http:WWW.herc.Com/ Food gums/index.htm.

[10] Hafelli, U, (Magnetically modulated therapeutic systems. International Journal of pharmaceutics, 277, 19-24, 2004.

[11] Gombotz W, Wee S F, "Adv. Drug Delivery Rev", 31-267, 1998.

[12] Ansari R, "Application of polyaniline and its composites for Adsorption/ Recovery of chromium (VI) from aqueous solutions". Acta Chim. solv, 53,88-94, 2006.

[13] Horsfall Jnr, A.I., Abia, A.A, "Sorption kinetics of $\mathrm{Pb}^{2+}$ and $\mathrm{Cu}^{2+}$ ions from aqueous solution by Nipah palm (Nypa fruticans Wurmb) shoot biomass", Chemical Society, 25(7), 969-976, 2004.
[14] Demirbas, A, "Adsorption of lead and cadmium ions in aqueous solutions onto modified lignin from alkali glycerol delignication", Journal of Hazardous Materials, 109(1-3), 221-226, 2004.

[15] Prabhakar M N, Chowdji K, and Subha M C.S "Prapartion and Characterization of .pH sensitive poly(vinyl alcohol)/ sodium carboxy methyl cellulose IPN microspheres for in vitro release studies of an anti-cancer drug. Polymer Bull”. 68(7), 1905-1919, 2012.

[16] Babel, Vijay, K.M., Debasish S. and Nayak P.L. "Chitosan-sodium alginate nanocomposites blended with cloistc $30 \mathrm{~B}$. As Anovel Drug delivery system for Anticancer Drug Curcumin". International Journal of Appled Biology and Pharmaceutical Technology. 2(3), 402-411, 2011.

[17] Lasko, C.L., Adams, K H, Debenedet, E M., West, P A, "A simple sulfuric acid pretreatment method to improve the adsorption of $\mathrm{Cr}(\mathrm{VI})$ by chitosan" Journal of Applied polymer science, 93(6), 28082814, 2004.

[18] Gary, U.K., Kaur, M.P., Gary, V.K., Sud, D, "Removal of hexavalent Chromium from aqueous solution by agricultural waste biomass", Journal of Hazardous Materials 140(1-2), 60-68, 2007.

[19] Yuh H. "Citation review of Lagergren kinetic rat equation on adsorption reactions" scintometric, 59(1), 171-177, 2004.

[20] Aksu Z, "Equilibrium and kinetic modelling of cadmium(II) biosorption by $C$. Vulgaris in a batch system: effect of temperature", Sep. Purif. Technol, 21(3), 285-294, 2001.

[21] M.Dogan, M.Aklan, and Turyilmaz A "Kinetics and mechanism of removal of methlene blue by adsorption onto perlite, J. Hazard 109(1-3), 141-148, 2004.

[22] Hassan Z M, Aborrahman H, and Vahdat $\mathrm{J}$, "studies of the adsorption Thermodynamics and kinetic of $\mathrm{Cr}$ (III) and $\mathrm{Ni}(\mathrm{II})$ removal by polyacrylamide". J.serb.chem.soc. 77(3)393-405, 2012. 
[23] Mor, K.S Ravidra and Biswas N., Bioresource Technol, 2007, 8, 3349.

[24] Freundlich H.Z, "phys chem.", 57, 384470, (1906).

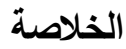

في هذا البحث تم دراسة امتزاز ايون الكروم السداسي من

محلوله المائي باستخدام بوليمرات حيوية محورة (صوديوم

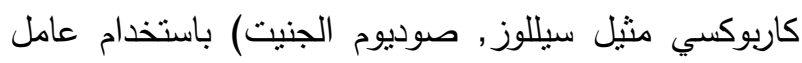

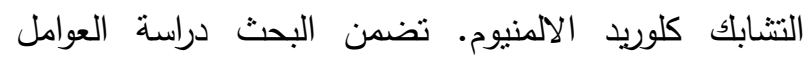

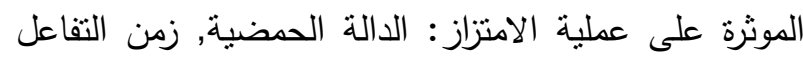

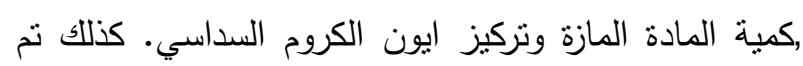
دراسة حركية امتزاز ايون الكروم السداسي باستخدام: المعادلة

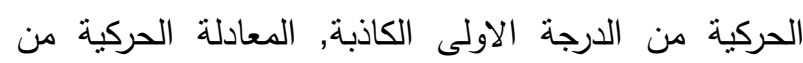

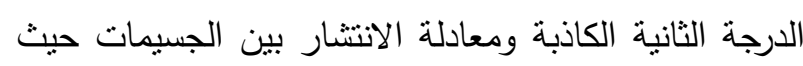
وجد ان الدراسة تخضع للمعادلة الحركية الكاذبة من الدرجة الثانية. كذلك نم دراسة ايزوثثرمات الامتزاز باستخدام معادلة فريندليش ولانكماير وتبين ان الامتزازلا يتبع كلا المعادلتين. 